\title{
The Use of Various Media on Hatchability, Hatching Time and The Vitality of Honey Cricket Tillers (Gryllus mitratus)
}

\author{
Ersan Riaji Lumban Tobing, Nevy Diana Hanafi*, and Sayed Umar \\ Animal Husbandry Study Program, Faculty of Agriculture, Universitas Sumatera Utara, Indonesia
}

\begin{abstract}
Crickets are the most demanded commodity because there have the most interest in ornamental livestock such as birds, while the presence of crickets in nature has diminwashed because their natural habitat has been increasingly eroded by city development. The important thing to consider in cricket farms was when incubating cricket eggs which requires special treatment to maintain their temperature and humidity. Thwas study aims toknow the hatching ability of cricket, egg hatching duration and the vitality of honey cricket age 0-10 days, in different media. The research was conducted at the Biology Laboratory of Animal Husbandry Study Program, Faculty of Agriculture, Universitas Sumatera Utara, Jl. A. Sofyan No. 3 Medan, which started from November 2018 until December 2018. The design used was a completely randomized design (CRD) 4 treatments (Q0: river sand hatch media; Q1: sand hatch media; Q2: kapok hatch media; Q3: rice straw hatch, and 5 replications (each conswasting of 100 honey cricket eggs Grylus mitratus).The use of various media for honey cricket hatching eggs has a positive influence on the hatchability of eggs, the duration of hatching eggs and the vitality of honey crickets tillers. River sand hatching media (P0) is the best hatching media for the parameters of hatching eggs of honey cricket and the vitality of honey crickets tillers.
\end{abstract}

Key words: hatchability, hatching media, hatching time, honey crickets, vitality

Received 08 December 2019 | Revised 19 February 2020 | Accepted 07 May 2020

\section{Introduction}

Aspects of the benefits of crickets in many studies mentioned that the nutritional content in cricket meat turned out to be beneficial for humans. The protein content was up to $65 \%$. Amino acid composition was quite complete, containing $23 \%$ of fat including omega 3 essential fatty acids, and omega 6 , and steroid hormones according to [1].

From the aspect of cricket nutrition has the potential as an alternative source of animal protein because it contains amino acids that was sufficiently complete so that it can partially replace soybean flour and fish meal in broiler chicken feed formulations according to [2].

\footnotetext{
*Corresponding author at: Animal Husbandry Study Program, Faculty of Agriculture, Universitas Sumatera Utara, Jl. Prof. Sofyan No. 3, Medan, 20155, Indonesia

E-mail address: nevydiana@yahoo.co.id
} 
The quality of cricket eggs has 2 classes according to [2] namely: high egg quality (good), that was if the hatchability was above 95\%; and low (bad) egg quality, if the hatchability was below $50 \%$. The quality of cricket eggs was influenced by several external factors, namely media and hatching time. According to [3] egg quality will decrease if environmental conditions are not suitable or eggs are infertile. Environmental conditions that cause a decreasing in the quality of the eggs are long periods of drought, which causes damage to the eggs. In addition, an unstable humid environment can also reduce the quality of eggs because humidity will cause the eggs to be attacked by disease or overgrown by fungi. All crooked or black eggs indicate the egg was ugly.

The purpose of thwas study was to determine the hatchability, hatching duration, and the vitality of cricket tillers in different hatching media.

\section{Material and Methods}

\subsection{Materials and Research Tools}

The research was conducted from November to December 2018, in the Biology Laboratory of Animal Husbandry Study Program, Faculty of Agriculture, Universitas Sumatera Utara. The materials used are cricket eggs, ant lime, roof nets, wood glue, plastic glass, rodalon, and hatching media. The tools used were made of cardboard enclosure maintenance of 20 units (with width $26 \mathrm{~cm}$, length $38 \mathrm{~cm}$ and height $23 \mathrm{~cm}$ ), plastic box 20 pieces (with a length of 20 $\mathrm{cm}$, width $12.5 \mathrm{~cm}$ and $2 \mathrm{~cm}$ ), spray tubes, duct tape, 80 mesh flour sieves, cage lighting tools, cage cleaning equipment, higrometers to see the temperature and humidity of the air in the cage room, as well as stationery to retrieve data.

\subsection{Research Parameters}

\subsubsection{Egg Hatchability}

Hatchability was calculated by counting the number of eggs that have successfully hatched from the number of eggs incubated. The number of eggs put in 1 cage provided from the carton was 100 eggs. There were 4 treatments and 5 replications so the number of carton cages needed was 20, and 2000 cricket eggs were needed. According to [2] the calculation of Hatchability percentage was calculated using the following formula:

$$
\text { Hatchability }=\frac{\text { Number of eggs that hatch }}{\text { Number of eggs taht incubated }} \times 100 \%
$$

\subsubsection{The Vitality of Crickets Tillers}

The vitality calculation was done by calculating the percentage of tillers who live from the total population of crickets that hatch until the age of 10 days [2]. The total number of cricket tillers that hatch in 1 cardboard cage divided by the number of tillers at one hundred percent. 


\subsubsection{Hatching time}

Hatching time calculation was done by calculating the time needed for the eggs since they were incubated until they hatch [4]. Cricket eggs took about 13-14 days to hatch According to [5].

\subsection{Research Implementation}

\subsubsection{Preparation of the cage}

Prepared maintenance cage material from a cardboard box for each treatment plot with a width of $26 \mathrm{~cm}$, a length of $38 \mathrm{~cm}$ and a height of $23 \mathrm{~cm}$ (glass-coated plastic on each inner wall of the box to prevent cricket tillers from coming out of the cardboard box) and all media cleaned and washed, then desinfected using rodalon with dilution of $15 \mathrm{ml}$ per 10 liters of water in accordance with the recommended use of rodalon.

\subsubsection{Hatching Media Preparation}

All media were sterilized by immersing in a mixture of rodalone and water by diluting $15 \mathrm{ml}$ of rodalone per 10 liters of water. Medium coarse sand hatching media was smoothed using flour sieves and must be moist. Hatching media has a height of $1.5 \mathrm{~cm}$ of sand bed and egg cover sand as high as $1 \mathrm{~mm}$. For medium cotton has a height of $2 \mathrm{~cm}$ as a base and not given an egg cover. Straw hatching media used straw that has been chopped with a length of $2-3 \mathrm{~cm}$ and placed in the plot evenly until it has a height of $2 \mathrm{~cm}$ as a base and not given a cover for eggs. For media cotton has a height of $2 \mathrm{~cm}$ as a base and not given an egg cover. Then placed even cricket eggs as much as 100 eggs on each side of the hatching media and put into a cage that has been provided.

\subsubsection{Cricket Egg Preparation}

Crickets used in the study amounted to 2000 eggs consisting of 4 treatments and 5 replications and each treatment consisted of 100 eggs. Cricket eggs used are fertile cricket eggs.

Honey cricket eggs were taken from Mr Lubwas's cricket farm in Jalan Bunga Mawar Padang Bulan, Medan City. The price of cricket eggs changes very quickly according to market conditions due to the fast cricket life cycle.

\subsubsection{Incubation Period}

The incubation period was carried out in the hatchery cage, as well as checking the eggs, checking the temperature and checking the humidity of the cage air using a higrometer. Thwas was done to prevent egg dryness and prevent egg fungus.

During the incubation period, observing and controlling the humidity and temperature of the cage 3 times a day (7:00 a.m., 3:00 p.m., and 11:00 p.m.) on the change in color of the eggs, and counting the eggs that have hatched from the 10th day to the 14th day on every treatment and repetition. 
After passing through the hatching period, cricket tillers are cared for and given chicory as feed in the maintenance box until the age of 10 days in an ad libitum. At the age of 10 days, cricket mortality was calculated per plot. According to [2], chicory was preferred by crickets because it has a high moisture content and has a non-hard texture.

Data was collected after the crickets hatched to determine the duration of hatching, and egg hatchability. Then the hatching crickets were kept for 10 days to find out their vitality.

The data obtained were analyzed stastically using variance analyswas. If among the treatments there was a significant it will be continued with Tukey's further tests.

\subsection{Data Analysis}

The study used a completely randomized design (CRD) method consisting of 4 treatments and 5 replications. The composition of the treatment given was as follows:

Q0 = Sand hatching media

Q1 = Kapok hatching media

Q2 = Rice straw hatching media

Q3 = Cotton hatching media

Thwas study uses 2000 honey cricket eggs to be incubated in 20 plot units, each unit was filled with 100 honey cricket eggs. Each experimental unit conswasted of 100 honey cricket eggs. The mathematical model used was as follows:

$$
\mathrm{Yij}=\mu+\tau \mathrm{i}+\varepsilon \mathrm{ij}
$$

where: $Y i j=$ treatment of the $\mathrm{i}$-th and $\mathrm{j}$-th replications; $\mathrm{M}=$ general score, $\tau \mathrm{i}=$ effect of $\mathrm{i}-\mathrm{i}$ treatment, $\varepsilon \mathrm{ij}=$ error (error) $\mathrm{i}$-nth replication treatment

Data were analyzed using the SPSS program for analyswas of variance (ANOVA). If different results were obtained that were significantly tested further with the Tukey test (Steel and Torrie 1993).

\section{Result and Discussion}

\subsection{Egg Hatchability (\%)}

Based on the results of further tests, it was known that the P0 treatment significantly influences the treatment of P1, P2 and P3. The results showed that the treatment of P0 (river sand) was the medium which had the highest average hatchability value of $77 \%$. The same thing was found in research [6] which showed that river sand hatching media were the best hatching media for hatchability parameters (with a percentage value of $66 \%$ ) among the other hatching media tested, because the river sand media was suitable as a place to hatch cricket eggs. But also because the sand resembles a form of life in nature, where crickets usually live in paddy fields 
or plantations. In nature the crickets live freely and if they lay eggs, eggs are only placed where the crickets are in the leaves, or in the sand. Wherever the crickets stayed, they will keep laying eggs even though the media does not exsist or was not suitable. The same thing was also shown in research [7] in the results of his research which found that the treatment of sand media and water spraying with vitamin B had the highest hatchability of the other hatched media tested.

Table 1. Average Hatchability of Honey Cricket Eggs Using Various Hatching Media (\%)

\begin{tabular}{ccccccc}
\hline \multirow{2}{*}{ Treatment } & \multicolumn{7}{c}{ Repetitions } & \multirow{2}{*}{ Average } \\
\cline { 2 - 6 } & $\mathbf{1}$ & $\mathbf{2}$ & $\mathbf{3}$ & $\mathbf{4}$ & $\mathbf{5}$ & \\
\hline Q0 & 77 & 78 & 76 & 77 & 77 & $77^{\mathrm{a}}$ \\
Q1 & 35 & 36 & 31 & 30 & 31 & $32.6^{\mathrm{c}}$ \\
Q2 & 32 & 33 & 34 & 33 & 33 & $33^{\mathrm{c}}$ \\
Q3 & 50 & 52 & 54 & 55 & 54 & $53^{\mathrm{b}}$ \\
\hline
\end{tabular}

Note: Different superscriptions in the same column show a real difference in the tukey test $(p<0.05)$

The difference in hatchability in each treatment was influenced by honey egg hatching media. Cricket hatchability was influenced by temperature and humidity of the hatching media. Each hatching media has the ability to maintain different humidity and temperatures. During observation, the P0 river sand hatch media has the ability to retain humidity and temperature better than other hatch media. The treatment of cotton hatching media P1 and cotton hatching media P2 were the most difficult to maintain moisture. Environmental conditions that do not support will damage the quality of cricket eggs so that the treatment of cotton hatch media P1 and cotton hatch media P2 treatment have low hatchability. In accordance with the opinion [8], which stated that egg quality will decrease in unsuitable environmental conditions. Low humidity will cause damage to the egg, and if it was too moist the egg will be easily overgrown with fungus or disease.

In the research, $\mathrm{P} 1$ treatment of cotton hatching media and P2 cotton hatching media have a low hatchability that was below $50 \%$, due to the lack of ability of hatching media to maintain temperature and humidity remain stable from external environmental conditions which have fluctuating temperatures and humidity. It was in accordance with the opinion [2] eggs that have good quality have high hatchability that was above $95 \%$, while low-quality hatchability was below $50 \%$.

\subsection{Hatching Time of Honey Cricket Egg}

The treatment of various honey cricket hatching media showed differences influenced by time and media that were different from each treatment. Treatment P2 (rice straw hatching media) was easier to dry than other hatching media, whereas treatment of P3 (rice straw hatching media) was able to maintain its moisture longer than other hatching media. Further research was needed on the effect of moisture in the hatch media on the hatching of honey cricket eggs. 
Table 2. The Average Length of Hatching Honey Cricket Eggs with Various Media

\begin{tabular}{ccccccc}
\hline \multirow{2}{*}{ Treatment } & \multicolumn{7}{c}{ Repetitions } & \multirow{2}{*}{ Average } \\
\cline { 2 - 6 } & $\mathbf{1}$ & $\mathbf{2}$ & $\mathbf{3}$ & $\mathbf{4}$ & $\mathbf{5}$ & \\
\hline Q0 & 48.80 & 49.80 & 48.80 & 49.44 & 50.14 & $49.39^{\mathrm{b}}$ \\
Q1 & 47.33 & 47.90 & 47.22 & 48.20 & 48.11 & $47.75^{\mathrm{b}}$ \\
Q2 & 44.00 & 43.50 & 44.00 & 46.71 & 49.00 & $45.44^{\mathrm{a}}$ \\
Q3 & 52.11 & 51.54 & 51.54 & 52.00 & 51.91 & $51.82^{\mathrm{c}}$ \\
\hline
\end{tabular}

Note: Different notations in the same column indicate a real difference in the tukey test $(\mathrm{p}<0.05)$

The results showed that the treatment of various hatching media significantly affected. The fastest hatching time was in treatment P2 (rice straw hatching media) with the value of the average time in hatching was in figure 45.44 an hour, while the longest average time of hatching was in treatment $\mathrm{P} 3$ (rice straw hatching) with the average hatching time was in number 51.8 hours.

\subsection{The Vitality of Honey Cricket Tiller}

The resultsshowed that the treatment of various hatching media significantly affected. It was consistent with research [6] which showed that the effect of cricket hatching media has a significant effect on the ability of hatching and survival of crickets (Gryllus testaceus), and research [7] which stated that the treatment give highly significant on the survival of cricket tillers 0-10 days $(\mathrm{P}<0.01)$.

Table 3. Average Survival Rate of Honey Cricket Tillers with Various Hatching Media (\%)

\begin{tabular}{ccccccc}
\hline \multirow{2}{*}{ Treatment } & \multicolumn{5}{c}{ Repetitions } & \multirow{2}{*}{ Average } \\
\cline { 2 - 6 } & $\mathbf{1}$ & $\mathbf{2}$ & $\mathbf{3}$ & $\mathbf{4}$ & $\mathbf{5}$ & \\
\hline Q0 & 85.06 & 92.05 & 86.05 & 84.88 & 82.76 & $86.16^{\mathrm{a}}$ \\
Q1 & 80.00 & 80.43 & 82.92 & 80.00 & 78.05 & $80.28^{\mathrm{b}}$ \\
Q2 & 83.33 & 83.72 & 84.09 & 81.39 & 79.55 & $82.42^{\mathrm{ab}}$ \\
Q3 & 83.33 & 83.87 & 82.81 & 80.00 & 80.95 & $82.19^{\mathrm{ab}}$ \\
\hline
\end{tabular}

Note: Different superscriptions in the same column show significant differences in the tukey test $(\mathrm{p}<0.05)$

Based on the results of further tests, it was known that the P0 treatment not significantly different with the treatment P1, P2, and P3The highest average vitality of cricket tillers was in treatment P0 (hatching media of river sand) with the average hatching capacity of cricket tillers was $86.16 \%$, while the lowest average survival rate of cricket tillers was in treatment P1 (hatching hatching media) with average value the vitality of cricket tillers was $80.28 \%$. It was not in accordance with the research [7] which showed that the use of cloth hatching media by spraying vitamin B complex has an average hatchability $(81.48 \%)$ higher than water hatching media with water spraying (77.13\%). However, it was different from the results of the study [6], which showed that the treatment of straw hatching media had better hatchability (81\%) than river sand hatching media (61\%).

Which stated that egg quality will decrease if environmental conditions are not suitable or eggs 
are infertile in accordance with statement [3]. Environmental conditions that cause a decrease in the quality of the eggs are long periods of drought, which causes damage to the eggs. In addition, an unstable humid environment can also reduce the quality of eggs because humidity will cause the eggs to be attacked by disease or overgrown by fungi. All crooked or black eggs indicate the egg was ugly. Then the possibility of survival of honey cricket tillers (Gryllus mitratus) was directly affected by egg quality and indirectly influenced by the environmental conditions of hatching media. Hatching media that are able to maintain conditions of temperature and humidity can maintain the quality of honey cricket eggs remain good, while the media that dries faster makes cricket eggs wrinkled and damaged. And media that was too wet will support the growth of fungus in honey cricket eggs so that they will be damaged.

From the observations during incubation of river sand hatching media ( $\mathrm{P} 0)$ was the best hatching media in maintaining humidity and from Table 3 river sand hatching media ( $\mathrm{P} 0)$ has the highest average survival of honey cricket tillers, $86.16 \%$, while the cotton hatching media (P1) and cotton hatching media (P2) have the ability to maintain poor humidity and cotton hatching media (P1) has the lowest average survival rate of honey cricket tillers that was $80.28 \%$. Accordance with statement [10] which stated that, one of the things that need to be considered in cricket cultivation was hatching cricket eggs. To be able to hatch, eggs must be given special treatment, especially the humidity must be maintained. However, the humidity of the egg must be in accordance with the desired conditions. If the egg was too moist it can cause failure to hatch, but if it was too dry, and also the statement [8] which states that, the quality of the egg will decrease in inappropriate environmental conditions. Low humidity will cause damage to the egg, and if it was too mowast the egg will be easily overgrown with fungus or dwasease.

\section{Conclusion and Recommendation}

The use of various media for honey cricket hatching eggs has a positive influence on the hatchability of eggs, the duration of hatching eggs and the vitality of honey crickets tillers. River sand hatching media (P0) is the best hatching media for the parameters of hatching eggs of honey cricket and the vitality of honey crickets tillers.

Based on the results of the study, it is recommended to use river sand as a medium for hatching honey cricket eggs (Gryllus mitratus). The author also suggests further research on the effect of media humidity on the duration of hatching of honey cricket eggs

\section{REFERENCES}

[1] Prayitno, "Pemurnian hormon estrogen dan testosteron dari jangkrik kalung," Laporan Penelitian, Fakultas Peternakan, Universitas Jenderal Soedirman., Purwokerto, 2006.

[2] P. Widyaningrum, "Pengaruh padat penebar dan jenis pakan terhadap produktivitas tiga 
spesies jangkrik ideal yang di budidayakan,” Disertasi, Program Pasca Sarjana., Institut Pertanian Bogor., Bogor, 2001.

[3] F. B. Paimin, I. E. Pudjiastuti, and Erniawati, Sukses Beternak Jangkrik. Cetakan I. Jakarta: Penebar Swadaya, 1999.

[4] S. E. Maharani, "Performa reproduksi jangkrik Cliring (Gryllus miratus) yang mendapat konsentrat dan daun singkong (Manihot esculenta, Cranzt) atau daun papaya (Carica papaya)," Skripsi, Fakultas Peternakan, Institut Pertanian Bogor., Bogor, 2004.

[5] G. Wiarto, Budi Daya Jangkrik, 2010. [Online] Available: http://elgwasha.files.wordpress.com/2010/03/budi-daya-jangkrik.ppt.

[6] D. Alina, A. Lusi, and R. Kasmeri, "Pengaruh media penetasan terhadap kemampuan tetas dan daya hidup jangkrik (Gryllus testaceus)," Skripsi, Program Studi Pendidikan Biologi., Sekolah Tinggi Keguruan Dan Ilmu Pendidikan PGRI Sumatera Barat., Padang, 2014.

[7] E. Sebayang, "Penggunaan media tetas dan penyemprotan vitamin b kompleks terhadap daya tetas jangkrik kalung (Gryllus bimaculatus)," Fakultas Pertanian, Universitas Sumatera Utara, Medan, 2016.

[8] H. Sukarno, Budidaya Jangkrik. Cetakan I. Yogyakarta: Kanisius, 1999.

[9] Sridadi dan Rachmanto, Teknik Beternak Jangkrik. Cetakan I. Yogyakarta: Kanisius 1999.

[10] F. B. Paimin, Mengatasi Permasalahan Jangkrik. Cetakan I. Jakarta: Penebar Swadaya, 1999. 